\title{
Analysis Of Environmental Effects On Adolescent Dating Patterns In The Pare Sub-District, Kediri Regency
}

\author{
Ratna Feti Wulandari*, Ratih Kusuma Wardhani, Vide Bahtera Dinastiti \\ STIKES Pamenang Kediri, Indonesia \\ * regianaia2014@gmail.com
}

\begin{abstract}
This study examined environmental effects that impact on dating patterns of adolescent in the Pare sub-district, Kediri Regency. Unhealthy dating patterns indicate adolescent sexual behavior when they were dating. The impact of sexual behavior is unwanted pregnancies and early marriages, thereby increasing the risk of infection during labor and even death and childbirth defects. This study aims to analyze the influence of environment on adolescent dating patterns. This research design used cross sectional method and the sample was collected on 300 respondents using the snowball sampling technique. Data was taken by questionnaire and analyzed using the Rank Spearmen Correlation test. The results showed that most of the respondents were in a sufficient environment $(71.0 \%)$ and their dating patterns were mostly in the healthy dating pattern category $(97 \%)$. The results of statistical testing showed that there was an environmental influence on the dating patterns of adolescents with a correlation coefficient of $-0.128(\mathrm{p}<0.05)$ with a significance level of 0.026. Finding the results of this study, it is necessary to increase a good environment, both the environment of family, peers, society, school, religious norms and other factors that affect adolescent dating patterns.
\end{abstract}

Keywords : Environment, Dating Patterns, Adolescent 


\section{STRADA Jurnal Ilmiah Kesehatan}

DOI: $10.30994 /$ sjik.v9i2.452

ISSN: 2252-3847 (print); 2614-350X (online)

Vol.9 No.2 November 2020 Page.1114-1120

\section{BACKGROUND}

Healthy and qualified adolescent will bring this nation to be good and advanced (Sarwono Prawirohardjo, 2009). In the adjustment stage, adolescents are susceptible to have problems. If there is occured, it can lead to deviant behavior. The number of adolescents in Indonesia is $27.6 \%$ of the total population or around 64 million people. The fact showed that some adolescents are now faced of premarital sex, drugs and others (BKKBN, 2019). Data indicates that an age of first marriage at a very young age $(<20$ years) as much as $46.7 \%$ of all married women. and 54.2 per 1000 women under the age of 20 have given birth (Kemenkes RI, 2015). Unhealthy dating patterns indicate premarital sexual behavior during adolescence. The impact of sexual behavior are early marriage and unwanted pregnancy. Less then 2020, early marriage is increasing, there was one hundred forty-two million young women will be married. Early marriage will bring about teenage girls at high risk of early pregnancy, whereas pregnancy is unwanted, increasing the risk of infection during labor and even threatens death and birth defects (BKKBN, 2019). Another risk was suffering from sexually transmitted diseases and lead to missed opportunities to continue education and psychological trauma.

Azinar's research (2013) showed that $12.1 \%$ of students have premarital sexual behavior that can raise the risk of unwanted pregnancy. The results of the research by Amalia and Azinar (2017) was the factors that influence the occurrence of unwanted pregnancy by adolescents are the sexual activity of respondents who are at risk, lack of knowledge about reproduction health and permissive attitudes towards premarital sex, access to information from media about pornography, parents who care less about their children, as well as the behavior of close friends. The environment affects adolescent development. Such as negative environment can make adolescents to behave unhealthy. It affects to sexual behaviorm of adolescent.

Pare District is one of the Districts in Kediri Regency, which consists of 10 villages where there is an English language training center known as "Kampung Inggris". There are schools and several colleges so that they are able to have their own charm for newcomers to study in that place. Therefore, further analysis is needed on environmental factors, namely by analyzing the influence of the environment on adolescent dating patterns.

\section{METHODS}

The research design used was cross sectional. The time of this study was from July to September 2020. There were 2 research variables, independent variable, namely the environment and dependent variable is the adolescent dating patterns. The population is all of adolescents in the District Area of Pare, Kediri Regency. The sample size was 300 adolescents that obtained by snowball sampling technique. The instrument used was a questionnaire that developed by the researcher and tested its validity and reliability. Subsequently data analysis used Spearman correlation test.

\section{RESULTS}

Table 1. Frequency distribution of respondents by age group.

\begin{tabular}{lll}
\hline Age range & Frequency (n) & Percentage (\%) \\
\hline Early adolescent & 33 & 11,0 \\
Middle adolescent & 145 & 48,3 \\
Late adolescent & 122 & 40,7 \\
\hline Total & 300 & 100
\end{tabular}




\section{STRADA Jurnal Ilmiah Kesehatan}

DOI: $10.30994 /$ sjik.v9i2.452

ISSN: 2252-3847 (print); 2614-350X (online)

Vol.9 No.2 November 2020 Page.1114-1120

Table 1 showed that most of adolescents are in middle adolescence, namely (48.3\%).

Table 2. Frequency distribution of respondents based on last education.

\begin{tabular}{lll}
\hline Education & Frequency $(\mathrm{n})$ & Percentage $(\%)$ \\
\hline Primary school & 21 & 7,0 \\
Junior High School & 94 & 31,3 \\
Senior High School & 174 & 58,0 \\
College & 11 & 3,7 \\
\hline Total & 26 & 100
\end{tabular}

Table 2 showed that most of the adolescents had the Senior high school education, namely $(58.0 \%)$.

Table 3. Frequency distribution of adolescent environment

\begin{tabular}{lll}
\hline Environment & $\begin{array}{l}\text { Frequenc } \\
\mathrm{y} \\
(\mathrm{n})\end{array}$ & $\begin{array}{l}\text { Percentage } \\
(\%)\end{array}$ \\
\hline Less & 12 & 4,0 \\
Moderate & 213 & 71,0 \\
Good & 75 & 25,0 \\
\hline Total & 300 & 100
\end{tabular}

Table 3 showed that most of the adolescent environment was in the moderate category, namely $(71.0 \%)$.

Table 4. Frequency Distribution of Adolescent Dating Patterns.

\begin{tabular}{lll}
\hline $\begin{array}{l}\text { Adolescent } \\
\text { Dating } \\
\text { Patterns }\end{array}$ & $\begin{array}{l}\text { Frekuens } \\
\text { i } \\
(\mathrm{n})\end{array}$ & $\begin{array}{l}\text { Prosentase } \\
(\%)\end{array}$ \\
\hline Unhealthy & 9 & 3,0 \\
Healthy & 291 & 97,0 \\
\hline Total & 300 & 100
\end{tabular}

Table 4 showed that most of the adolescent dating patterns were in the healthy dating pattern category $(97.0 \%)$.

Table 5. Results of Environmental Influence Analysis on Adolescent Dating Patterns

\begin{tabular}{llllc}
\hline & & \multicolumn{2}{l}{$\begin{array}{l}\text { Environment } \\
\text { Score }\end{array}$} & $\begin{array}{l}\text { Dating } \\
\text { Pattern }\end{array}$ \\
\hline $\begin{array}{l}\text { Spearm } \\
\text { an's } \\
\text { Rho }\end{array}$ & Environment Score & Correlation Coefficient & 1,000 &,$- 128^{*}$ \\
& & & & \\
& & Sig. (2-tailed) & - &, 026 \\
& & $\mathrm{~N}$ & 300 & 300 \\
\cline { 2 - 5 } & Environment Score & Correlation Coefficient &,$- 128^{*}$ & 1,000 \\
& & Sig. (2-tailed) &, 026 & - \\
& & $\mathrm{N}$ & 300 & 300 \\
\hline
\end{tabular}




\section{STRADA Jurnal Ilmiah Kesehatan}

DOI: $10.30994 /$ sjik.v9i2.452

ISSN: 2252-3847 (print); 2614-350X (online)

Vol.9 No.2 November 2020 Page.1114-1120

Table 5 showed that the results of the analysis test by Spearman Correlation obtained $\mathrm{p}<\alpha ; \alpha=0.05$ then Ho is rejected, thus it means that there was an environmental influence adolescent dating patterns with a correlation coefficient of $r=-0.128$ with a significance level of 0.026 which indicates that the better environment, the more healthy dating pattern will be.

\section{DISCUSSION}

\section{Adolescent Dating Patterns}

Healthy dating patterns are physically, mentally, socially, sexually and emotionally healthy, whereas unhealthy dating patterns consist of kising, necking, petting and intercourse (Agustini, N. Kadek Nadia, 2019). The results of this study were mostly adolescent dating patterns in the healthy dating pattern category (97.0\%). Healthy dating patterns may be influenced by adolescent knowledge about dating patterns and the impact of unhealthy dating patterns. It complianced with the research of Umaroh, A, Kusumawati, and Kasjono (2015) which knowledge is one of the factors that can influence adolescent behavior in dating patterns, free sex, pregnancy before marriage and abortion.

Knowledge is an important part of behavior conformation. Knowledge which is based on knowledge will be more lasting. It is appropiate with the results of research by Agustini, Ni Kadek Nadia (2019) which is stated that the knowledge of young women about healthy dating is $70.2 \%$ in a good category, young women who take premarital sexual precautions, namely $66.0 \%$ where the better the knowledge of young women about healthy dating, the more adolescents take action to prevent premarital sexual behavior.

The factors that influenced knowledge are education, age, environment and sociocultural (Wawan, A 2010). The majority of adolescents from this study were in the middle adolescent age group (48.3\%). It can be explained that adolescents with the middle adolescent group are characterized by looking for identity, idealistic thinking, and there is a narcissistic tendency, namely choosing friends who have the same characteristics as themselves. The increasing age of a person affects maturity in attitude and behavior so that individuals will be more considerate and be careful (Sarwono, S, 2012).

Most of the adolescents had a high school education (58.0\%). Higher education levels make it easier for a person to receive information and will be careful in behaving. Research by Fahmi, Ikhsan, Sri Wahyuni (2017) stated that the higher level of education of adolescents will reduce actions that violate the rules, norms and values in the surrounding environment.

\section{Adolescents Environment}

The environment is a big factor in its role of child development. The Adolescents environment consists of the school environment, peers, family, community, and sociocultural.

The results showed that most of the adolescent environment was in the moderate category $(71.0 \%)$. A positive environment will configurate children's behavior to be positive. It conformed with Hasanah's research results (2017) that adolescents in their development are strongly influenced by the social environment such as family and school friends, the environment provided stimuli that can affect the development of adolescents, there are biologically, psychologically and sociocultural. A social environment that gives adolescent's freedom and big opportunities for adolescents to grow and develop as well as 


\section{STRADA Jurnal Ilmiah Kesehatan}

DOI: $10.30994 /$ sjik.v9i2.452

ISSN: 2252-3847 (print); 2614-350X (online)

Vol.9 No.2 November 2020 Page.1114-1120

provide good supervision and stimulation, so the environment has helped adolescents in conforming and looking for self-identity.

\section{Environmental Effects on Adolescent Dating Patterns}

The results showed that there was an influence between the environment on the dating patterns of adolescents with a correlation coefficient of $r=-0.128$ which indicated that the better the environment, the healthier the dating pattern was.

The results showed that a good adolescent's environment affected adolescent dating patterns so that a positive environment will form a healthy dating pattern. Unhealthy dating patterns such as kissing, necking, petting and intercourse are adolescent sexual behaviors. This is also supported by Fitriadi Machmut's (2018) research's, the factors of doing taaruf (healthy dating) were factors of religious education, parental factors and adolescent's relationships.

The religious education factor influenced the dating pattern of adolescents, this is a significant relationship between the religious environment and premarital sex behavior where the environment in the Islamic boarding school can configurate positive behavior (Khairunnisa, A, 2013).

The family environment also affects adolescent sexual behavior, according to the research of Haryani, D Wahyuningsih, W, Haryani K (2015) that the role of parents is related to adolescent sexual behavior. Putri, Berliana D (2014) stated that premarital sexual behavior is influenced by gender, parenting styles, family communication patterns and family's form.

The dating pattern of adolescents is also influenced by peers, it complianced with the research of Berliana, N, S, Idei K, Dw Sumarni (2017) which explained that peers contributed greatly to adolescent dating behavior.

Social media is an environmental factor that also affects adolescent dating patterns where social media is an easy access of information that everyone can get which can have a negative impact on free sex, it convenient with the research of Hastuti, Nur Indah, Safrudin Bachtiar (2018) that there was significant correlation between the use of social media and dating behavior in seventh and eighth grade adolescents.

The results of the Spearman's correlation analysis test $r=-0.128$, sig $(p)=0.026$ indicated that the effect is very low, so that the environment is not the only factor that influenced the dating pattern of adolescents. It can be seen that the results of this study are adolescent environment in the moderate category. However, the adolescents environment is still an important factor in adolescent development, so that a good environment is needed to make good adolescents.

\section{CONCLUSION}

There was an influence between the environment and the adolescents dating pattern in the Pare District, Kediri Regency with $\mathrm{p}<\alpha ; \alpha=0.05$. From the results of these studies, it is necessary to improve the environment that supports both family, peer, school and community as well as religion so that adolescents do not engage in unhealthy dating patterns. For further research, it can be investigated about the factors that influence adolescent dating patterns.

\section{ACKNOWLEDGEMENT}

This research was fully funded by the Directorate of Research and Community Service, Directorate General of Research and Development Strengthening of the Ministry of 


\section{STRADA Jurnal Ilmiah Kesehatan}

DOI: $10.30994 /$ sjik.v9i2.452

ISSN: 2252-3847 (print); 2614-350X (online)

Vol.9 No.2 November 2020 Page.1114-1120

Research, Technology and Higher Education in accordance with the Research Contract Number : 131 / SP2H / LT-MONO / LL7 / 2020. We would like to thank to Head of Pare Sub-District and Headman of urban village in the Pare Sub-District who facilitated the implementation of this research.

\section{REFERENCES}

Agustini,Ni Kadek Nadia.(2019). Hubungan Pengetahuan Remaja Putri Tentang Pacaran Sehat dengan Tindakan mencegah hubungan seksual Pranikah di SMA Negeri Denpasar. Skripsi. Kementrian Kesehatan R.I.Politeknik Kesehatan Kemenkes Denpasar Jurusan Kebidanan Denpasar. Di akses tanggal 17 februari 2020 http://repository.poltekkes-denpasar.ac.id/2008/

Amalia,E dan Azinar M.(2017). Kehamilan tidak diinginkan pada Remaja. HIGIE.journal of publich health research and development. Di akses tanggal 19 februari 2020 http://journal.unnes.ac.id/sju/index.php/higea

Azinar M.(2013). Perilaku Seksual Pranikah Beresiko terhadap Kehamilan Tidak Diinginkan .Jurnal Kesehatan Masyarakat: 8 (2) 153-160 diakses tanggal 10 februari 2020 https://journal.unnes.ac.id/nju/index.php/kemas/article/view/2639/2706

Berliana Novi,S.Idei Kurnia,Dw Sumarni. (2017). Peranan Pola Asuh Ibu Dan Teman Sebaya Pada Perilaku Pacaran Remaja Sma Di Kota Jambi. http://etd.repository.ugm.ac.id/home/detail_pencarian/103661

BKKBN. (2019). Siaran Pers No.RILIS/47/B4/BKKBN/VII/2019. https://www.bkkbn.go.id/detailpost/genre-educamp-2019-upaya-bkkbnhadapi-permasalahan-remaja

Fahmi, Ikhsan,Sri Wahyuni. (2017). Determinan Perilaku Seksual Pranikah Remaja Pria Di Indonesia Hasil Sdki. https://www.researchgate.net/publication/334717789_Determinan_Perilaku_Seksual_ Pra_Nikah_Remaja_Pria_di_Indonesia_Hasil_SDKI

Fitriadi, Machmut.(2018). Pola Pacaran Mahasiswa IAIN Salatiga Dalam Perspektif Hukum Islam.Skripsi.Program Studi Hukum Islam Fakultas Syariah Institut Agama Islam Negeri (IAIN) Sala tiga Di akses tanggal 14 februari 2020 http://erepository.perpus.iainsalatiga.ac.id/5012/1/SKRIPSI\%20MACHMUT.pdf

Haryani, D Wahyuningsih, W, Haryani K .(2015).Peran Orang Tua Berhubungan Dengan Perilaku Seksual Pra Nikah Remaja Di Smkn 1 Sedayu. Ners dan Kebidanan Indonesia. http://ejournal.almata.ac.id/index.php/jkni/article/view/170.

Hasanah, Uswatun.(2017). Pengaruh Terapi Kelompok Terapeutik Remaja Dan Psikoedukasi Keluarga Terhadap Perkembangan Identitas Diri Remaja. http://journal.stikeskendal.ac.id/index.php/Keperawatan/article/view/47

Hastuti, Nur Indah, Safrudin, Bachtiar. (2018). Hubungan Penggunaan Media Sosial Dengan Perilaku Berpacaran Pada Remaja Kelas Vii Dan Viii Di Smpn 7 Samarinda. https://dspace.umkt.ac.id/bitstream/handle/463.2017/835/NASKAH\%20PUBLIKASI $\%$ 20WORD.pdf? sequence $=1$ \&isAllowed $=\mathrm{y}$

Kemenkes RI. (2015). Rencana Strategis Kemenkes RI.Jakarta: Kemenkes RI.

Khairunnisa, Ayu.(2013). Hubungan Religiusitas Dan Kontrol Diri Dengan Perilaku Seksual Pranikah Remaja Di Man 1 Samarinda. e journal psikologi I (2):22029.http://ejournal.psikologi.fisip-unmul.ac.id/site/wp.content/uploads/2013/ejournal pdf (10-03-13-10-14-57). Pdf.

Nuraldila,V dan Yuhandini, D.(2017). Keterkaitan pengetahuan tentang kesehatan reproduki remaja dengan perilaku seks pra nikah pada siswa-siswi kelas XI di 


\section{STRADA Jurnal Ilmiah Kesehatan}

DOI: $10.30994 /$ sjik.v9i2.452

ISSN: 2252-3847 (print); 2614-350X (online)

Vol.9 No.2 November 2020 Page.1114-1120

SMA PGRI 1 Kabupaten Majalengka. Jurnal care vol 5 No 3. Diakses tanggal 24 februari 2020 https://jurnal.unitri.ac.id/index.php/care/article/view/710

Putri, Berliana D.(2014). Peran Faktor Keluarga Dan Karakteristik Remaja Terhadap Perilaku Seksual Pranikah. http://journal.unair.ac.id/filerPDF/biometrikfde8cc6696full.pdf

Rohmawati, Indah dan Sukanto.(2020). Pengetahuan Dan Perilaku Kesehatan Reproduksi Remaja Terkait Pola Pacaran, Sex Bebas, Kehamilan Di Luar Nikah Dan Aborsi. http://journal.stikeskendal.ac.id/index.php/Keperawatan/article/view/718

Sarwono Prawirohardjo.(2009).Ilmu Kebidanan. Jakarta:Bina Pustaka Sarwono Prawirohardjo

Sarwono,S.W.(2012).Psikologi Remaja.Jakarta:PT Rajagrafindo persada.

Umaroh, A.K, Kusumawati, Y, Kasjono, H.S. (2015). Hubungan Antara Faktor Internal Dan Faktor Eksternal Dengan Perilaku Seksual Pranikah Remaja Di Indonesia. Kesehatan Masyarakat Andalas. http://jurnal.fkm.unand.ac.id/index.php/jkma/article/view/165.

Wawan, A. (2010). Teori Dan Pengukuran Pengetahuan, Sikap Dan Perilaku Manusia.Yogyakarta: Nuha Medika

Widyastuti, Rahmawati dan Purnamaningrum.(2009). Kesehatan Reproduksi. Jakarta: Fitramaya 